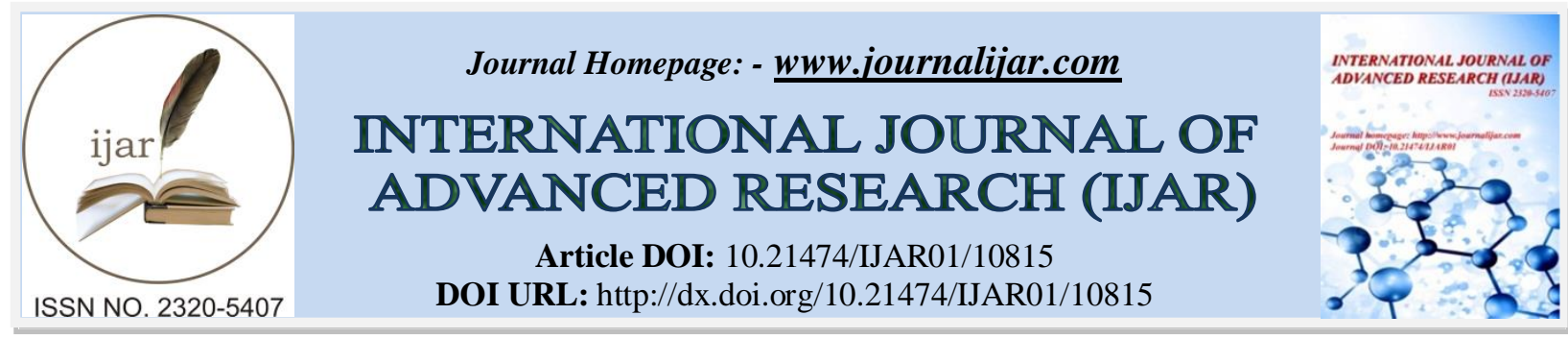

RESEARCH ARTICLE

\title{
MICROBIAL COUNTS AND IDENTIFICATION OF LACTIC ACID BACTERIA ASSOCIATED WITH READY TO DRINK ZOOM-KOOM COLLECTED FROM SELLING PLACES IN OUAGADOUGOU, BURKINA FASO
}

\section{Adama M.A.R. Soma ${ }^{1,2}$, Clarisse S. Compaoré ${ }^{1}$, Irène L.I. Ouoba ${ }^{3}$, Donatien Kaboré ${ }^{1}$, Charles Parkouda ${ }^{1}$,} Abel Tankoano ${ }^{1}$, Aboubacar Toguyeni ${ }^{2}$ and Hagrétou Sawadogo-Lingani ${ }^{1}$

1. Département Technologie Alimentaire (DTA), Institut de Recherche en Sciences Appliquées et Technologies (IRSAT), Centre National de la Recherche Scientifique et Technologique (CNRST). 03 BP.7047 Ouagadougou 03, Burkina Faso.

2. Université Nazi BONI (ex Université Polytechnique de Bobo-Dioulasso), 01BP.1091 Bobo Dioulasso 01. Burkina Faso.

3. Microbiology Research Unit, Faculty of Life Sciences, School of Human Sciences, London Metropolitan University, London, 166-220 Holloway Road, London N7 8DB, UK.

\section{Manuscript Info}

\section{Manuscript History}

Received: 12 February 2020

Final Accepted: 14 March 2020

Published: April 2020

Key words:-

Zoom-Koom, Millet, Microbial Counts, Identification, LAB, Burkina Faso

\section{Abstract}

Zoom-koom is a very popular millet based beverage which has social and economic importance in Burkina Faso. The aim of this study was to investigate physico-chemical and microbiological characteristics, especially genotypic diversity of the predominant lactic acid bacteria (LAB) associated to commercial zoom-koom collected in the twelve districts of the city of Ouagadougou. Physico-chemical and microbiological characteristics were determined using standard methods. Identification of microorganisms included phenotyping, Rep-PCR typing and sequencing of $16 \mathrm{~S}$ rRNA. The $\mathrm{pH}$ of the ready to drink zoom-koom samples varied from 3.2 to 4.4 while the acidity varied from 0.69 to $4.1 \mathrm{~g}$ of lactic acid $/ 100 \mathrm{~mL}$. Regarding the type of grains used to produce zoomkoom, $65 \%$ of the producers used unshelled millet grains, $23 \%$ used shelled grains, and $12 \%$ used both types of grains. LAB, enterobacteria and yeasts and molds counts ranged between $4.2 \times 10^{5}$ to $7.6 \times 10^{8}$ $\mathrm{CFU} / \mathrm{mL}, 1 \times 10^{1}$ to $7.1 \times 10^{5} \mathrm{CFU} / \mathrm{mL}$ and $1.7 \times 10^{3}$ to $2.1 \times 10^{6} \mathrm{CFU} / \mathrm{mL}$, respectively. Results showed that most of the commercial zoom-koom collected in front of schools and health centers of the twelve districts do not respect microbiological criteria of quality for enterobacteria and yeasts and molds. At the species level, Lactobacillus plantarum subsp. plantarum dominated $(41.66 \%)$ zoom-koom vended nearby schools and health centers, followed by Pediococcus pentosaceus (37.5\%) and Lactobacillus fermentum (20.83\%).

Copy Right, IJAR, 2020,. All rights reserved.

\section{Introduction:-}

The zoom-koom is a popular beverage of Burkina Faso, usually prepared from the millet grains (Tapsoba et al, 2017b). The production of the zoom-koom involved several steps including sorting of millet grains, peeling, soaking in water during $13 \mathrm{~h}$, washing, draining of the grains, mixing with ginger $(6 \mathrm{~g} / 100 \mathrm{~g})$ and mint $(3 \mathrm{~g} / 100 \mathrm{~g})$, milling, 
filtration and sweetening with sugar $(2500 \mathrm{~g} / 5 \mathrm{~L})$. It is mainly produced by women and has important socioeconomic implications (Soma et al., 2017). Street-vended foods and beverages like zoom-koom production processes are dominated by the intervention of hands without adhering to good hygienic practices and therefore are susceptible to contamination by pathogenic microorganisms (Sunday et al., 2011; Bsadjo-Tchamba et al., 2014). Consequently, from the same producers, the quality varied from one production to another due to the use of non-standards methods. Recently, an innovative process of zoom-koom production from whole grains including fermentation of the dough before filtering allowed to improve the microbiological quality with a notable reduction of enterobacteria counts (Tapsoba et al., 2017a). In addition, others recent studies allowed to identify Lactic Acid Bacteria (LAB) associated to the different steps of zoom-koom production process and demonstrated the capacity of some of the isolates belonging to the species to be used as starter cultures (Tapsoba et al, 2017b; 2018).

The improvement of the hygienic quality of zoom-koom by the use of LAB was recently confirmed by the use of $L$. fermentum isolated from dolo (traditional sorghum beer) which was successfully used as a starter culture during zoom-koom production. The results indicated a reduction of pathogen and an increase of hygienic, nutritional and sensorial quality of the final product (Soma et al, 2019). Zoom-koom is a street drink sold everywhere in the city of Ouagadougou, in markets, on roadsides, in front of schools and medical centers (hospitals, dispensaries). Its microbiological quality can have serious consequences on the health of consumers, especially those who are vulnerable such as children and sick or convalescent people. It is sold in bulk or packaged in plastic bags or plastic recovery bottles which increases the risk of contamination.

To our knowledge, the microbiological quality and the biodiversity of LAB in zoom-koom ready to drink sold in Ouagadougou has not been reported before. The aim of this study was to determine microorganisms counts and identify the LAB associated with zoom-koom sold in front of school and health centers of the 12 districts of the city of Ouagadougou.

\section{Materials and Methods:- Sampling of zoom-koom:}

Different selling sites of zoom-koom were visited in the 12 districts of the city of Ouagadougou in Burkina Faso (Fig 1). Selling sites were located either in front of schools or in front of health centers. After discussion with the producers/sellers, the processing steps were recorded and samples were collected in sterile plastic bottles, kept in a thermo-cooler with ice blocs and transported to the laboratory of Département Technologie Alimentaire (DTA/IRSAT/CNRST) for physicochemical and microbiological analyses within $24 \mathrm{~h}$. Ten samples (2 per producers/sellers) were collected in each district. A total of 120 samples were then taken in the 12 districts coded D1 to D12 and composed of 102 samples collected in front of schools and 18 samples collected in front of health centers.

\section{Physico-chemical characterization:}

The $\mathrm{pH}$ of the samples was measured directly in $10 \mathrm{~mL}$ of beverage (Sawadogo-Lingani et al., 2007) using an electronic $\mathrm{pH}$ meter (Model HI 8520, Hanna Instrument, Singapore). For the determination of the titratable acidity, 5 $\mathrm{mL}$ of sample suspended in $50 \mathrm{~mL}$ ethanol (90\%) were centrifuged for $5 \mathrm{~min}$ at $3500 \mathrm{~g}$. From the supernatant, 10 $\mathrm{mL}$ were transferred in a flask and filled up to $50 \mathrm{~mL}$ with distilled water. After mixing, $10 \mathrm{~mL}$ of the diluted sample were titrated with $0.1 \mathrm{~N} \mathrm{NaOH}$ using $1 \%$ phenolphthalein as an indicator (Sawadogo-Lingani et al., 2007). The titratable acidity (g of lactic acid per $100 \mathrm{~mL}$ of sample) was calculated according to Amoa-Awua et al. (1996).

\section{Enumeration of microorganisms:}

Ten grams of each sample were aseptically homogenized in $90 \mathrm{~mL}$ of sterile diluent $(0.1 \%$ peptone, $0.8 \% \mathrm{NaCl}, \mathrm{pH}$ $7.0 \pm 0.2$ ) using a stomacher (stomacher 400 lab blender, England) at normal speed for 2 min to obtain $10^{-1}$ dilution. Serial dilutions were made from the homogenate of all samples, using $9 \mathrm{~mL}$ sterile diluent. Enumeration of LAB according to ISO (International Standard Organization) 15214 (1998) was obtained by pouring one milliliter from ten-fold dilutions in Man, Rogosa and Sharp (MRS, Liofilchem, Spain) incubated anaerobically in an anaerobic jar with anaerocult (Merck) at $37{ }^{\circ} \mathrm{C}$ for 72 to $96 \mathrm{~h}$. After incubation, plates with 15-300 colony forming units (CFU) were counted and results expressed as $\mathrm{CFU} / \mathrm{mL}$. Yeasts and molds were enumerated by pour plate on Dextrose Chloramphenicol Agar (DCA, Liofilchem, Spain), pH $6.6 \pm 0.2$ incubated at $30^{\circ} \mathrm{C}$ for 3 to 5 days according to ISO 7954 (1988). Enterobacteria were enumerated using Violet Red Bile Glucose agar (VRBG, Liofilchem, Spain), incubated at $37^{\circ} \mathrm{C}$ for $24 \mathrm{~h}$ according to ISO 7402 (1993). Plates of DCA and VRBG containing 15 to 150 colonies were retained for the counting and results were expressed as $\mathrm{CFU} / \mathrm{mL}$ of sample. 


\section{Isolation, purification and preliminary characterization of LAB isolates:}

For isolation of lactic acid bacteria, 10 colonies were randomly chosen from the highest dilution MRS plate of each sample and were purified by successive streaking on MRS agar under anaerobic conditions using anaerobic jar and anaerocult (Merck). Pure cultures were maintained at $-80{ }^{\circ} \mathrm{C}$ in MRS broth (Liofilchem, Spain) containing $20 \%$ (v/v) glycerol. Working cultures were kept at $4{ }^{\circ} \mathrm{C}$ on MRS agar. All pure isolates were characterized by colony morphology, cell morphology using phase contrast microscopy (Olympus optical, BX 40F-3, Japan), Gram reaction using 3\% $\mathrm{KOH}$ as described by Gregersen (1978), and catalase reaction using 30\% $\mathrm{H}_{2} \mathrm{O}_{2}$ solution (Barrow and Feltham, 1993). In addition, the production of gas by LAB isolates using the semi-solid medium of Gibson and Abdel-Malek (Guiraud, 1998), their ability to grow in MRS broth at $15{ }^{\circ} \mathrm{C}$ and $45^{\circ} \mathrm{C}$, in MRS broth at pH 9.2, in MRS broth containing $6.5 \% \mathrm{NaCl}$ (Ennadir et al, 2014) and their ability to hydrolyze arginine (Thomas, 2000) were also tested. The fermentation of sugars was carried out using the media of fermentation for Lactobacillus (MRS) and the Streptococci (M17) containing the chlorophenol red as indicator. The solutions were distributed in test tubes (9 $\mathrm{mL} /$ tube) to which were added at the time of using $1 \mathrm{~mL}$ of a $5 \%$ sugar solution sterilized by filtration. The tubes were inoculated and incubated at $37{ }^{\circ} \mathrm{C}$ for 3 to 7 days. Results are positive if the color of the indicator changes. The studied sugars were maltose, raffinose, sucrose, glucose, lactose, xylose, starch, arabinose and fructose (SawadogoLingani et al., 2008).

\section{Genotypic characterization of LAB isolates:}

The isolates were streaked on MRS agar and incubated anaerobically at $37{ }^{\circ} \mathrm{C}$ for $48 \mathrm{~h}$. DNA from a pure colony was extracted using the InstaGene Matrix extraction kit (Biorad 732-6030, Hemel Hempstead, UK) according to the manufacturer's instructions. The extracted DNA was then stored at $-20{ }^{\circ} \mathrm{C}$ for later use (Ouoba et al., 2012).

Based on preliminary characterization, presumptive LAB isolates were grouped using rep-PCR and isolates from each group were determined. The reaction mixture $(25 \mu \mathrm{L})$ consisted of $2.5 \mu$ LGitschier $10 \mathrm{X}$ buffer, $2.0 \mu \mathrm{L}$ of DMSO $(100 \%), 10.25 \mu \mathrm{L}$ of pure water, $4 \mu \mathrm{L}$ of dNTP $(25 \mathrm{mM}$ each ), $4 \mu \mathrm{L}$ of primers (GTG) 5 (5'GTGGTGGTGGTGGTG-3' $)(0.3 \mu \mathrm{g} / \mu \mathrm{L}), 0.25 \mu \mathrm{L}$ of Taq Polymerase $(5 \mathrm{U} / \mu \mathrm{L})$ and $2 \mu \mathrm{l}$ DNA $\left(50 \mathrm{ng} . \mu \mathrm{L}^{-1}\right)$. The amplification reactions were carried out using the Gene AmpR PCR System 2700 thermal cycler (Applied biosystems, USA) according to Ouoba et al. (2010).

Electrophoresis was carried out on agarose gel at 1.5\% (w/v) (Gellyphor, EuroClone) and amplicons were purified with GFX ${ }^{\mathrm{TM}}$ PCR DNA and Gel Band Purification Kit (GE Healthcare). Molecular weight of the amplified DNA fragments was estimated by comparison with a $1 \mathrm{~Kb}$ plus DNA Ladder (Invitrogen) ranging from 100 to 12,000 bp. Sequencing was carried out at GATC Laboratories, Germany. The same protocol as for rep-PCR was used for the extraction and purification of DNA intended for sequencing. To identify suspected LAB, two primers were used. The primer $\mathrm{pD}$ (5'GTATTACCGCGGCTGCTG-3 ') corresponding to $550 \mathrm{bp}$ was first used as described by Ouoba et al., (2008). For isolates with an unspecified identity, the primer pairs (Invitrogen Life Technologies, Milan, Italy), LacbF / LacbR (5'TGCCTAATACATGCAAGT-3' and 5'-CTTGTTACGACTTCACCC-3') corresponding to positions 369-386 respectively and 1424-1441 of the Lactobacillus mucosae AF126738 RNA gene sequence were then used to amplify the fragment of the 16S rRNA gene of the isolates selected for sequencing as described by De Angelis et al. (2006). The reaction mixture $(50 \mu \mathrm{L})$ consisted of $10.25 \mu \mathrm{L}$ of Master Mix (QiAgen, France), $0.5 \mu \mathrm{L}$ of each sense and antisense primer, $37.75 \mu \mathrm{L}$ of milliQ water and $1 \mu \mathrm{L}$ of each extracted DNA. A negative control and a positive control were performed (Taale et al., 2016). The electrophoresis was carried out on $1.5 \%(\mathrm{w} / \mathrm{v})$ agarose gel (Gellyphor, EuroClone) and the amplified fragments were purified with the GFX TM PCR DNA kit and Gel Band Purification Kit (GE Healthcare). The molecular weight of the amplified DNA fragments was estimated by comparison with a weight marker of $1 \mathrm{~Kb}$ Plus (Invitrogen) ranging from 100 to 12,000 bp. The sequences obtained were compared with those available on GenBank (National Center for Information on Biotechnology, Bethesda, MD, USA) using the BLAST program (http://www.ncbi.nlm.nih.gov/genbank/ ) according to Wang et al. (2007) then on EZbiocloud (https://www.ezbiocloud.net/) which constitutes a database containing only 16S RNA sequences of reference strains (Yoon et al., 2017). The dendrograms were produced using Mega7 and BioEdit software.

\section{Statistical analyses of data:}

All the data were submitted to analysis of variance (ANOVA) with the statistical software XLSTAT-Pro 7.5.2 and the means were compared using the test of Student Newman-keuls to the probability level $p<0.05$.

\section{Results and Discussion:-}

Physico-chemical characteristics of ready to drink zoom-koom: 
The investigation on the production processing steps of the zoom-koom sold in the 12 districts of Ouagadougou, revealed that for the zoom-koom sold in front of schools, all the sellers/producers of 6 districts (D1, D3, D6, D9, D10 and D11) from the 12 used unshelled millet grains. The sellers/producers from 2 districts (D2 and D8) used shelled grains while the sellers/producers of 4 districts (D4, D5, D7 and D12) used shelled and unshelled grains to produce zoom-koom (Table 1). For the type of millet grains used to produce zoom-koom sold in front of health centers, all the sellers/producers of 4 districts (D2, D3, D10 and D12) from the 5 investigated used unshelled grains and sellers/producers of 1 district (D11) used the 2 types of grains (shelled and unshelled). No information regarding the type of grain used to produce zoom-koom sold in front of health centers from districts D1, D4, D5, D6, D7, D8 and D9 was obtained due to the absence of sellers in front of these health centers (Table 1).

The physico-chemical parameters of the zoom-koom sold in front of schools and health centers are presented in Table 1. For the zoom-koom sold in front of schools, $\mathrm{pH}$ varied from 3.2 to 4.3 while acidity varied from 0.9 to $4.1 \mathrm{~g}$ of lactic acid/100 mL. There was no significant difference between $\mathrm{pH}$ values of zoom-koom collected in the 12 districts. Likewise, there was no significant difference between values of acidity of the zoom-koom from the 12 districts.

Concerning the zoom-koom sold in front of health centers, thevalues of $\mathrm{pH}$ and acidity varied from 3.25 to 4.4 and 0.69 to $1.8 \mathrm{~g}$ lactic acid/100 $\mathrm{mL}$, respectively. As for the samples of zoom-koom sold nearby schools, there was no significant difference between $\mathrm{pH}$ values, as well as between acidity values of zoom-koom sold in the front of health centers for the 5 districts.

Higher $\mathrm{pH}$ values were reported by Tapsoba and collaborators in 2017 during production of zoom-koom in two productions sites of two districts of the city of Ouagadougou (sector Dassasgho in district D10 and sector Zogona in district D5). Indeed, these authors found a variation of $\mathrm{pH}$ of 3.8 to 5.5 for the zoom-koom produced in Zogona production site and a variation of $\mathrm{pH}$ of 3.5 to 5.2 for the zoom-koom produced in Dassasgho production site. The acidity of zoom-koom collected in front of schools and health centers varied between 0.69 to $4.1 \mathrm{~g}$ of lactic acid/100 $\mathrm{mL}$ of product. Zoom-koom from Zogona and Dassasgho studied by Tapsoba et al (2017a) were more acid with acidity values ranging from 3.8 to $6.3 \mathrm{~g}$ of lactic acid $/ 100 \mathrm{~mL}$ of product. These differences of $\mathrm{pH}$ and acidity may be due to differences in the technologies used to produce the zoom-koom. Indeed, the production of the zoom-koom is preceded by a soaking step of the millet grains in water, during which a lactic fermentation takes place leading to a drop of the $\mathrm{pH}$ and an increase in the acidity of the drink (Soma et al., 2019). According to Messens et De Vuyst (2002), decrease of $\mathrm{pH}$ could be due to the growth of the lactic acid bacteria which are recognized as being producing organic acids (like lactic acid, acetic acid, formic acid, phenolic and caproic acids). Moreover,the addition of tamarind could also justify this fall of pH of the zoom-koom. From the hygienic point of view, this acidification is a major asset, because it inhibits the growth of the majority of the pathogenic agents (Tchekessi et al, 2014).

Lactic acid bacteria (LAB), enterobacteria, yeasts and molds counts in ready to drink zoom-koom:

Table 2 shows variation of the microbial population of the zoom-koom sold in front of schools and health centers. For the zoom-koom sold in front of the schools, LAB, enterobacteria and yeasts and molds counts varied from $4.0 \times 10^{5}$ to $3.0 \times 10^{8} \mathrm{CFU} / \mathrm{mL}, 1.0 \times 10^{1}$ to $2.4 \times 10^{5} \mathrm{CFU} / \mathrm{mL}$ and $6.6 \times 10^{3}$ to $2.1 \times 10^{6} \mathrm{CFU} / \mathrm{mL}$, respectively. The analysis of the results showed that there wasno significant difference between LAB counts of zoom-koom samples collected from districts D2, D3, D5 and D10 as well as from districts D1, D6, D7, D9 and D12. LAB counts from district D8 and D11 were also not significantly different. Enterobacteria counts of zoom-koom from districts D2, D3 and D5 were not significantly different. Likewise, there was no significant difference between enterobacteria counts of zoom-koom from districts D4, D6, D7, D8, D9 and D11. However, there was significant difference between enterobacteria counts for zoom-koom of districts D1 and D12. Results also showed that yeasts and molds counts of zoom-koom from districts D1, D4, D5 and D10 were not significantly different. In addition, there was no significant difference between yeasts and molds counts of zoom-koom from districts D6, D7, D8, D9, D11 and D12.

Seven districts (D4, D6, D7, D8, D9, D11 and D12) out of 12 presented samples contaminated by enterobacteria with loads varying between $10^{4}$ to $10^{5} \mathrm{CFU} / \mathrm{mL}$. Concerning yeasts and molds, 7 districts (D3, D6, D7, D8, D9 and D12) also presented samples with yeasts and molds loads ranging from $10^{5}$ to $10^{6} \mathrm{CFU} / \mathrm{mL}$. These loads do not comply with the microbiological criteria established by the guide of health ministry of Luxembourg (2018) which set a limit of $10^{2}(\mathrm{~m})$ to $10^{3}(\mathrm{M}) \mathrm{CFU} / \mathrm{mL}$ for enterobacteria and $10^{3}(\mathrm{~m})$ to $10^{4}(\mathrm{M}) \mathrm{CFU} / \mathrm{mL}$ for yeasts and molds in soft drinks. 
Regarding the zoom-koom sold in front of health centers, $\mathrm{LAB}$, enterobacteria and yeasts and molds counts varied respectively from $6.1 \times 10^{5}$ to $7.6 \times 10^{8} \mathrm{CFU} / \mathrm{mL}, 1.2 \times 10^{3} \mathrm{CFU} / \mathrm{mL}$ to $7.1 \times 10^{5} \mathrm{CFU} / \mathrm{mL}$ and $1.7 \times 10^{3}$ to $1.5 \times 10^{6}$ $\mathrm{CFU} / \mathrm{mL}$. The analysis showed that there was no significant difference between LAB counts for zoom-koom of districts D2 and D10 in one hand and for zoom-koom of districts D3 and D11 on the other hand. Loads of enterobacteria of zoom-koom from districts D3, D11 and D12 were not significantly different. However, enterobacteria loads of zoom-koom from district D2 were significantly different from those of districts D3, D11 and D12. There was no significant difference between yeasts and molds counts of zoom-koom from districts D2 and D11. In the opposite, yeasts and molds counts of zoom-koom from districts D3 and D12 were significantly different to yeasts and molds counts of zoom-koom from districts D2 and D11.

Two districts (D2 and D10) from the 5 visited in front of health centers had samples with enterobacteria loads (104 to $\left.10^{5} \mathrm{CFU} / \mathrm{mL}\right)$ higher than the limit set $\left(10^{2}\right.$ to $\left.10^{3} \mathrm{CFU} / \mathrm{mL}\right)$ by the microbiological criteria of the guide of the health ministry of Luxembourg (2018). Similarly, 2 districts (D3 and D12) presented samples which yeasts and molds loads $\left(10^{5}\right.$ to $\left.10^{6} \mathrm{CFU} / \mathrm{mL}\right)$ do not respect the limit $\left(10^{3}\right.$ to $\left.10^{4} \mathrm{CFU} / \mathrm{mL}\right)$ set by the guide of the health ministry of Luxembourg (2018).

In summary, the results showed that most of the zoom-koom samples sold in front of schools and health centers are of unsatisfactory hygienic quality in terms of enterobacteria and yeasts and molds.However, the variation of enterobacteria loads $\left(1 \times 10^{1}-2.4 \times 10^{5} \mathrm{CFU} / \mathrm{mL}\right)$ from ready to drink zoom-koom sold in front of schools are lower than the variation of enterobacteria counts $\left(1.2 \times 10^{3}-7.1 \times 10^{5} \mathrm{CFU} / \mathrm{mL}\right)$ in ready to drink zoom-koom sold in front of health centers. This difference could be explained by the fact that health centers are privileged environments for pathogenic germs while schools are not. Health centers are the sites most often visited by people suffering from all forms of illnesses. These diseases are most of the time caused by microorganisms (pathogenic bacteria or viruses). These pathogenic bacteria which are present in the ambient air can easily be found in the foods and drinks sold nearby (Barro et al, 2007).

Tapsoba and collaborators in 2017 obtained a variation of LAB, enterobacteria, yeasts and molds ranging between $8.4 \times 10^{7}$ to $1.1 \times 10^{8} \mathrm{CFU} / \mathrm{mL}, 8.6 \times 10^{2}$ to $2.8 \times 10^{7} \mathrm{CFU} / \mathrm{mL}$ and $1.7 \times 10^{3}$ to $4.0 \times 10^{5} \mathrm{CFU} / \mathrm{mL}$, respectively in one production site of the sector of Zogona. In the production site of the sector of Dassasgho, they obtained a variation of $\mathrm{LAB}$, enterobacteria, yeasts and molds ranging between $2.6 \times 10^{6}$ to $5.0 \times 10^{8} \mathrm{CFU} / \mathrm{mL}, 2.2 \times 10^{5}$ to $2.4 \times 10^{6}$ $\mathrm{CFU} / \mathrm{mL}$ and $5.3 \times 10^{3}$ to $2.5 \times 10^{5} \mathrm{CFU} / \mathrm{mL}$, respectively. The difference in the variation of germs as enterobacteria and yeasts and molds compared to our study may be explained by the origin of the raw material used, the hygiene of production and the environment in which is carried out the production, as well as the selling conditions of the zoomkoom. Indeed, Bsadjo-Tchamba and collaborators in 2014 showed that the zoom-koom sold in 18 markets of the town of Ouagadougou contained a strong content of pathogenic enterobacteria like Escherichia coli and Salmonella. The loads of enterobacteria obtained in this study are similar to those obtained by Elmahmood and collaborators (2007) during a study on kunun-zaki, a drink which is similar to zoom-koom in Nigeria. Amusa and collaborators (2009) also reported a low load of enterobacteria for samples of kunun-zaki beverage sold in Gerei town of Adamawa State in Nigeria.

Identification of lactic acid bacteria isolated from ready to drink zoom-koom:

A total of $440 \mathrm{LAB}$ were isolated from the zoom-koom samples collected from selling places in front of schools (351 isolates) and health centers (89 isolates) in Ouagadougou. The isolates were characterized as non-motile, gram positive, catalase negative and oxidase negative bacteria. $62.5 \%$ of these isolates were rods and $37.5 \%$ of the isolates were cocci in tetrad. Tables 3 and 4 showed the characteristics of 24 representatives of the 440 LAB isolates obtained from the results of the preliminary macroscopic, microscopic and physiological characterization tests carried out on the isolates.

The results from Table 3 showed that all the isolates were able to grow in anaerobic conditions. All of them (100\%) were V.P negative and nitrate negative. $66.66 \%$ of LAB isolates hydrolyzed the arginine while $33.34 \%$ did not hydrolyze the arginine. $4.16 \%$ of isolates were gelatin positive while $95.84 \%$ were negative to this test. $2.83 \%$ of isolates were indol positive and $79.17 \%$ were indol negative. $25 \%$ of isolates were positive for the test of Gibson and Abel Malek and produced gas from glucose whereas $75 \%$ were negative to this test. $37.5 \%$ of isolates were positive to the test of casein hydrolysis and $62.5 \%$ were negative to this test. 
For their ability to ferment sugars (Table 4), all the isolates tested (100\%) fermented fructose and glucose while $79.16 \%, 41.66 \%, 87.5 \%, 62.5 \%, 50 \%, 70.83 \%$ and $62.5 \%$ of them fermented maltose, starch, saccharose, lactose, xylose, raffinose and arabinose, respectively.

The 24 representatives of the 440 LAB isolates were clustered by (GTG) 5-based rep-PCR, dividing the isolates into 8 clusters (results not shown). Representatives isolates of each cluster were identified based on their 16S rRNA gene sequence followed by BLAST search at EzBioCloud (Table 5, Fig 2). The isolates of rep-PCR group 1 showed 99.75\% 16S rRNA gene identity to L. plantarum subsp. plantarum. The isolates of rep-PCR groups 2, 4, 5, 6, 7 and 8 showed $100 \% 16 \mathrm{~S}$ rRNA gene identity to $P$. pentosaceus. The isolates of rep-PCR group 3 showed $99.36 \% 16 \mathrm{~S}$ rRNA gene identify to L. fermentum. The dominant LAB species found in zoom-koom ready to drink sold in the 12 districts of the city of Ouagadougou (Burkina Faso) were L. plantarum subsp. plantarum (41.66\%), P. pentosaceus (37.5\%) and L. fermentum (20.83\%). Tapsoba and collaborators in 2017 showed that LAB in zoom-koom isolated from Zogona and Dassasgho districts contained L. plantarum/pentosus, Lactococcus lactis, Lactococcus arvieae and Weissella cibaria/confusa. Efiuvwevwere and Akona (1995) who studied the microbiology of the fermentation process of Kunun-zaki also reported the presence of L. fermentum in addition to Lactobacillus leichmanniias dominant LAB at the end of the fermentation period. In dolo (sorghum based fermented beverage from Burkina Faso) production process, various LAB such as L. fermentum, Lactobacillus delbrueckii subsp. delbrueckii, L. delbrueckii subsp. Bulgaricus and Pediococcus acidilactici were reported to be involved in the production of dolo wort (Sawadogo-Lingani et al., 2007).

\section{Sugar fermentation profil of the LAB species predominant in ready to drink zoom-koom:}

All the 10 isolates $(100 \%)$ of L. plantarum subsp. plantarum were able to ferment glucose, fructose, saccharose and maltose, while $90 \%$ of them fermented raffinose. $80 \%$ of these isolates fermented arabinose, lactose and xylose and $60 \%$ of them fermented starch (Table 6).

For the 5 isolates of L. fermentum, all of them (100\%) fermented glucose, fructose, saccharose, maltose and raffinose; $80 \%$ of them fermented arabinose and lactose. $60 \%$ of them fermented xylose and $40 \%$ fermented starch (Table 6).

All the 9 isolates of $P$. pentosaceus (100\%) were able to ferment glucose and fructose. $66.66 \%$ of them fermented saccharose and $44.44 \%$ fermented maltose. $33.33 \%$ of these isolates fermented raffinose, arabinose and lactose while $22.22 \%$ fermented starch and $11.11 \%$ fermented xylose (Table 6).

The ability of LAB species to ferment different sugars has been reported in previous studies. Indeed, Belhamra et al. (2016) showed that L. plantarum isolated from fresh bee pollen were able to ferment raffinose, maltose and saccharose but did not ferment arabinose and xylose. They also found isolates of $P$. pentosaceus fermenting maltose, galactose and fructose but not fermenting xylose and raffinose. During the study on the predominant LAB associated with the traditional malting of sorghum grains, Sawadogo-Lingani et al. (2010) identified 62 isolates of $L$. fermentum and showed that these isolates had the capacity to ferment fructose, glucose, arabinose, sucrose but not starch. $94 \%$ of the isolates had the capacity to ferment maltose and raffinose compared to $88 \%$ and $70 \%$ of the isolates which ferment xylose and lactose, respectively. In addition, the same study found that 26 isolates of $P$. acidilactici/pentosaceus had the capacity to ferment glucose, fructose, lactose, sucrose, xylose, raffinose and starch. $80 \%$ of the Pediococcus isolates identified by Sawadogo et al. (2010) could ferment arabinose compared to $20 \%$ for maltose. The difference in the sugars fermentation profiles of the isolates of LAB species could be explained by the variability of the phenotypic characteristics of the isolates within the same species. Indeed, a diversity of LAB isolates within species with regard to their ability to ferment carbohydrates has been demonstrated (Lei and Jakobsen, 2004; Sawadogo-Lingani et al, 2010).

\section{Conclusion:-}

This study revealed that the zoom-koom sold near health services presents a greater risk of contamination than the zoom-koom sold near schools. Results showed that ready to drink zoom-koom contained different microorganisms like LAB, enterobacteria and yeasts and molds. Concerning LAB, L. plantarum subsp. plantarum was the dominant bacteria follow-up by $P$. pentosaceus and L. fermentum. 
Table 1: Variation of the physico-chemical parameters of ready to drink zoom-koom sold in front of schools and health centers.

\begin{tabular}{|c|c|c|c|c|c|c|}
\hline \multirow{2}{*}{$\begin{array}{l}\text { Codes of } \\
\text { districts }\end{array}$} & \multicolumn{3}{|c|}{ Zoom-koom sold in front of schools } & \multicolumn{3}{|c|}{ Zoom-koom sold in front of health centers } \\
\hline & Types of grains used & pH at $25^{\circ} \mathrm{C}$ & $\begin{array}{l}\text { Acidity } \\
(\mathrm{g} / 100 \mathrm{~mL})\end{array}$ & $\begin{array}{l}\text { Types of grains } \\
\text { used }\end{array}$ & $\begin{array}{l}\text { pH } \\
\text { at } 25^{\circ} \mathrm{C}\end{array}$ & $\begin{array}{l}\text { Acidity } \\
\text { (g/100mL) }\end{array}$ \\
\hline D1 & Unshelled & $3.7 \pm 0.05^{\mathrm{a}}$ & $1.7 \pm 0.2^{b}$ & n.d & n.d & n.d \\
\hline D2 & Shelled & $3.8 \pm 003^{\mathrm{a}}$ & $2.6 \pm 0.01^{\mathrm{b}}$ & Unshelled & $4.1 \pm 0.00^{\mathrm{a}}$ & $1.5 \pm 0.03^{\mathrm{b}}$ \\
\hline D3 & Unshelled & $3.3 \pm 0.05^{\mathrm{a}}$ & $1.4 \pm 0.18^{\mathrm{b}}$ & Unshelled & $3.25 \pm 0.00^{\mathrm{a}}$ & $1.3 \pm 0.05^{\mathrm{b}}$ \\
\hline D4 & Shelled/Unshelled & $4.3 \pm 0.07^{\mathrm{a}}$ & $0.9 \pm 0.04^{\mathrm{b}}$ & n.d & n.d & n.d \\
\hline D5 & Shelled /Unshelled & $4.2 \pm 0.004^{\mathrm{a}}$ & $1.6 \pm 0.07^{\mathrm{b}}$ & n.d & n.d & n.d \\
\hline D6 & Unshelled & $3.5 \pm 0.002^{\mathrm{a}}$ & $1.8 \pm 0.1^{\mathrm{b}}$ & n.d & n.d & n.d \\
\hline D7 & Shelled /Unshelled & $3.8 \pm 0.006^{\mathrm{a}}$ & $0.9 \pm 0.06^{\mathrm{b}}$ & n.d & n.d & n.d \\
\hline D8 & Shelled & $3.5 \pm 0.002^{\mathrm{a}}$ & $1.4 \pm 0.13^{\mathrm{b}}$ & n.d & n.d & n.d \\
\hline D9 & Unshelled & $3.2 \pm 0.004^{\mathrm{a}}$ & $3.2 \pm 0.00^{\mathrm{b}}$ & n.d & n.d & n.d \\
\hline D10 & Unshelled & $4.1 \pm 0.003^{\mathrm{a}}$ & $4.1 \pm 0.00^{\mathrm{b}}$ & Unshelled & $4.4 \pm 0.00^{\mathrm{a}}$ & $0.78 \pm 0.00^{\mathrm{b}}$ \\
\hline D11 & Unshelled & $3.4 \pm 0.007^{\mathrm{a}}$ & $3.4 \pm 0.01^{\mathrm{b}}$ & Shelled/Unshelled & $3.6 \pm 0.00^{\mathrm{a}}$ & $1.8 \pm 0.24^{\mathrm{b}}$ \\
\hline D12 & Shelled/Unshelled & $3.4 \pm 0.007^{\mathrm{a}}$ & $3.4 \pm 0.007^{\mathrm{b}}$ & Unshelled & $3.3 \pm 0.00^{\mathrm{a}}$ & $0.69 \pm 0.09^{\mathrm{b}}$ \\
\hline
\end{tabular}

Each column values having a common letter are not significantly different according to the Student Newman Keuls test at the 5\% threshold.

n.d: not determined.

\section{Acknowledgement:-}

The authors are grateful to the PAES-UEMOA project $N^{\circ}$ P- Z1-IAD-002 ( ${ }^{\circ}$ DU DON: 2100155007376), for their financial support of a part of the present work. The authors also are thankful to the HAAGRIM program for the financial support.

Table 2:-Microbial populations of ready to drink zoom-koom sold in front of schools and health centers.

\begin{tabular}{|c|c|c|c|c|c|c|}
\hline \multirow[b]{2}{*}{$\begin{array}{l}\text { Codes of } \\
\text { districts }\end{array}$} & \multicolumn{3}{|c|}{ Zoom-koom sold in front of schools } & \multicolumn{3}{|c|}{ Zoom-koom sold in front of health centers } \\
\hline & $\begin{array}{l}\text { LAB } \\
(\text { CFU/mL) }\end{array}$ & $\begin{array}{l}\text { Enterobacteria } \\
\text { (CFU/mL) }\end{array}$ & $\begin{array}{l}\text { Yeasts and } \\
\text { molds } \\
(\text { CFU/mL) }\end{array}$ & $\begin{array}{l}\text { LAB } \\
(\text { CFU/mL) }\end{array}$ & $\begin{array}{l}\text { Enterobacteria } \\
\text { (CFU/mL) }\end{array}$ & $\begin{array}{l}\text { Yeasts and } \\
\text { molds } \\
(\text { CFU/mL })\end{array}$ \\
\hline $\begin{array}{l}\mathrm{D} 1 \\
(\mathrm{n}=10)\end{array}$ & $(1.44 \pm 0.7) 10^{7 \mathrm{a}}$ & $(1.0 \pm 0.5) 10^{1 \mathrm{a}}$ & $(5.6 \pm 2.8) 10^{4 a}$ & n.d & n.d & n.d \\
\hline $\begin{array}{l}\mathrm{D} 2 \\
(\mathrm{n}=10)\end{array}$ & $(1.0 \pm 0.5) 10^{6 \mathrm{~b}}$ & $(2.7 \pm 1.3) 10^{2 b}$ & $(6.6 \pm 3.3) 10^{3 \mathrm{~b}}$ & $(6.1 \pm 3.0) 10^{5 \mathrm{a}}$ & $(2.8 \pm 1.4) 10^{4 \mathrm{a}}$ & $(6.8 \pm 3.0) 10^{4 \mathrm{a}}$ \\
\hline $\begin{array}{l}\mathrm{D} 3 \\
(\mathrm{n}=10)\end{array}$ & $(2.8 \pm 1.4) 10^{6 \mathrm{~b}}$ & $(1.9 \pm 0.9) 10^{2 b}$ & $(2.1 \pm 1.0) 10^{6 \mathrm{ab}}$ & $(3.5 \pm 1.7) 10^{6 \mathrm{~b}}$ & $(1.2 \pm 0.6) 10^{3 \mathrm{~b}}$ & $(1.5 \pm 0.7) 10^{6 b}$ \\
\hline $\begin{array}{l}\mathrm{D} 4 \\
(\mathrm{n}=10)\end{array}$ & $(4.0 \pm 2.0) 10^{5 \mathrm{ab}}$ & $(2.5 \pm 1.2) 10^{4 a b}$ & $(4.5 \pm 2.2) 10^{4 a}$ & n.d & n.d & n.d \\
\hline $\begin{array}{l}\text { D5 } \\
(\mathrm{n}=10)\end{array}$ & $(3.0 \pm 1.0) 10^{6 \mathrm{~b}}$ & $(2.9 \pm 1.4) 10^{2 b}$ & $(5.4 \pm 2.8) 10^{4 a}$ & n.d & n.d & n.d \\
\hline $\begin{array}{l}\text { D6 } \\
(\mathrm{n}=10)\end{array}$ & $(3.8 \pm 1.9) 10^{7 a}$ & $(3.0 \pm 1.8) 10^{4 a b}$ & $(2.5 \pm 1.2) 10^{5 \mathrm{c}}$ & n.d & n.d & n.d \\
\hline $\begin{array}{l}\text { D7 } \\
(\mathrm{n}=10)\end{array}$ & $(3.8 \pm 1.8) 10^{7 \mathrm{a}}$ & $(5.0 \pm 2.5) 10^{4 a b}$ & $(2.9 \pm 1.5) 10^{5 \mathrm{c}}$ & n.d & n.d & n.d \\
\hline $\begin{array}{l}\text { D8 } \\
(\mathrm{n}=10)\end{array}$ & $(3.0 \pm 1.5) 10^{8 \mathrm{c}}$ & $(3.4 \pm 1.7) 10^{4 a b}$ & $(2.1 \pm 1.0) 10^{5 \mathrm{c}}$ & n.d & n.d & n.d \\
\hline $\begin{array}{l}\text { D9 } \\
(\mathrm{n}=10)\end{array}$ & $(4.1 \pm 1.7) 10^{7 \mathrm{a}}$ & $(3.5 \pm 1.7) 10^{4 a b}$ & $(2.1 \pm 1.0) 10^{5 \mathrm{c}}$ & n.d & n.d & n.d \\
\hline $\begin{array}{l}\text { D10 } \\
(\mathrm{n}=10)\end{array}$ & $(4.7 \pm 2.3) 10^{6 \mathrm{~b}}$ & $(4.8 \pm 2.4) 10^{3 \mathrm{c}}$ & $(3.6 \pm 1.8) 10^{4 a}$ & $(7.7 \pm 3.8) 10^{5 a}$ & $(7.1 \pm 3.5) 10^{5 \mathrm{ab}}$ & $(1.7 \pm 0.8) 10^{3 \mathrm{ab}}$ \\
\hline $\begin{array}{l}\text { D11 } \\
(n=10)\end{array}$ & $(2.4 \pm 1.2) 10^{8 \mathrm{c}}$ & $(1.4 \pm 0.7) 10^{4 a b}$ & $(2.4 \pm 1.2) 10^{5 \mathrm{c}}$ & $(2.7 \pm 1.8) 10^{6 b}$ & $(3.2 \pm 2.0) 10^{3 \mathrm{~b}}$ & $(3.2 \pm 1.6) 10^{4 \mathrm{a}}$ \\
\hline $\begin{array}{l}\text { D12 } \\
(\mathrm{n}=10)\end{array}$ & $(3.5 \pm 1.7) 10^{7 \mathrm{a}}$ & $(2.4 \pm 1.4) 10^{5 \mathrm{ac}}$ & $(2.2 \pm 1.0) 10^{5 \mathrm{c}}$ & $(7.6 \pm 3.6) 10^{8 \mathrm{ab}}$ & $(7.3 \pm 3.6) 10^{3 \mathrm{~b}}$ & $(9.8 \pm 4.9) 10^{5 \mathrm{c}}$ \\
\hline
\end{tabular}


Each column values having a common letter are not significantly different according to the Student Newman Keuls test at the 5\% threshold.

n.d: not determined, n: number of samples collected.

Table 3: Morphological, physiological and biochemical characteristics of the LAB isolated from ready to drink zoom-koom.

\begin{tabular}{|c|c|c|c|c|c|c|c|c|c|c|c|c|c|c|c|c|c|c|c|c|c|c|c|c|}
\hline $\begin{array}{l}\text { Cod } \\
\text { es of } \\
\text { isola } \\
\text { tes }\end{array}$ & $\begin{array}{l}\text { S } \\
\mathbf{A} \\
\mathbf{1}\end{array}$ & $\begin{array}{l}\text { S } \\
\text { A } \\
2\end{array}$ & $\begin{array}{l}\text { S } \\
\mathbf{A} \\
\mathbf{3}\end{array}$ & $\begin{array}{l}\text { S } \\
\text { A } \\
4\end{array}$ & $\begin{array}{l}\mathbf{S} \\
\mathbf{A} \\
\mathbf{5}\end{array}$ & $\begin{array}{l}\text { S } \\
\text { A } \\
6\end{array}$ & $\begin{array}{l}\text { S } \\
\mathbf{A} \\
7\end{array}$ & $\begin{array}{l}\mathbf{S} \\
\mathbf{A} \\
\mathbf{8}\end{array}$ & $\begin{array}{l}\text { S } \\
\mathbf{A} \\
\mathbf{9}\end{array}$ & $\begin{array}{l}\text { S } \\
\mathbf{A} \\
\mathbf{1 0}\end{array}$ & $\begin{array}{l}\text { S } \\
\mathbf{A} \\
\mathbf{1 1}\end{array}$ & $\begin{array}{l}\mathbf{S} \\
\mathbf{A} \\
\mathbf{1 2}\end{array}$ & $\begin{array}{l}\text { S } \\
\text { A } \\
\mathbf{1 3}\end{array}$ & $\begin{array}{l}\text { S } \\
\text { A } \\
14\end{array}$ & $\begin{array}{l}\text { S } \\
\text { A } \\
15\end{array}$ & $\begin{array}{l}\text { S } \\
A \\
16\end{array}$ & $\begin{array}{l}\text { S } \\
\text { A } \\
17\end{array}$ & $\begin{array}{l} \\
A \\
18\end{array}$ & $\begin{array}{l}\text { S } \\
\text { A } \\
19\end{array}$ & $\begin{array}{l}\text { S } \\
\mathbf{A} \\
20\end{array}$ & $\begin{array}{l} \\
A \\
21\end{array}$ & $\begin{array}{l}\mathbf{S} \\
\mathbf{A} \\
\mathbf{2 2}\end{array}$ & $\begin{array}{l}S \\
A \\
23\end{array}$ & $\begin{array}{l}\text { S } \\
\text { A } \\
24\end{array}$ \\
\hline $\begin{array}{l}\text { Shap } \\
\mathrm{e}\end{array}$ & $\begin{array}{l}\text { S } \\
\text { ho } \\
\text { rt } \\
\text { ro } \\
\text { ds }\end{array}$ & $\begin{array}{l}\text { C } \\
\text { oc } \\
\text { ci } \\
\text { in } \\
\text { tet } \\
\text { ra } \\
\text { d }\end{array}$ & $\begin{array}{l}\text { lo } \\
\mathrm{n} \\
\mathrm{g} \\
\text { ro } \\
\mathrm{d} \\
\mathrm{s}\end{array}$ & $\begin{array}{l}\text { sh } \\
\text { or } \\
\text { t } \\
\text { ro } \\
\mathrm{ds}\end{array}$ & $\begin{array}{l}\mathrm{C} \\
\mathrm{oc} \\
\mathrm{ci} \\
\text { in } \\
\text { tet } \\
\mathrm{ra} \\
\mathrm{d}\end{array}$ & $\begin{array}{l}\mathrm{C} \\
\text { oc } \\
\text { ci } \\
\text { in } \\
\text { tet } \\
\mathrm{ra} \\
\mathrm{d}\end{array}$ & $\begin{array}{l}\mathrm{C} \\
\mathrm{oc} \\
\mathrm{ci} \\
\text { in } \\
\text { tet } \\
\mathrm{ra} \\
\mathrm{d}\end{array}$ & $\begin{array}{l}\mathrm{S} \\
\text { ho } \\
\text { rt } \\
\text { ro } \\
\text { ds }\end{array}$ & $\begin{array}{l}\text { S } \\
\text { ho } \\
\text { rt } \\
\text { ro } \\
\text { ds }\end{array}$ & $\begin{array}{l}\text { Sh } \\
\text { or } \\
\text { t } \\
\text { ro } \\
\mathrm{ds}\end{array}$ & $\begin{array}{l}\text { lo } \\
\text { ng } \\
\text { ro } \\
\text { ds }\end{array}$ & $\begin{array}{l}\text { lo } \\
\text { ng } \\
\text { ro } \\
\text { ds }\end{array}$ & $\begin{array}{l}\mathrm{C} \\
\mathrm{oc} \\
\mathrm{ci} \\
\text { in } \\
\text { tet } \\
\text { ra } \\
\mathrm{d}\end{array}$ & $\begin{array}{l}\mathrm{C} \\
\text { oc } \\
\text { ci } \\
\text { in } \\
\text { tet } \\
\text { ra } \\
\text { d }\end{array}$ & $\begin{array}{l}\text { lo } \\
\text { ng } \\
\text { ro } \\
\text { ds }\end{array}$ & $\begin{array}{l}\text { lo } \\
\text { ng } \\
\text { ro } \\
\text { ds }\end{array}$ & $\begin{array}{l}\text { lo } \\
\text { ng } \\
\text { ro } \\
\text { ds }\end{array}$ & $\begin{array}{l}\mathrm{C} \\
\text { oc } \\
\text { ci } \\
\text { in } \\
\text { tet } \\
\text { ra } \\
\text { d }\end{array}$ & $\begin{array}{l}\text { Sh } \\
\text { or } \\
\mathrm{t} \\
\text { ro } \\
\mathrm{ds}\end{array}$ & $\begin{array}{l}\mathrm{C} \\
\mathrm{oc} \\
\mathrm{ci} \\
\text { in } \\
\text { tet } \\
\mathrm{ra} \\
\mathrm{d}\end{array}$ & $\begin{array}{l}\text { Sh } \\
\text { or } \\
\text { t } \\
\text { ro } \\
\text { ds }\end{array}$ & $\begin{array}{l}\text { Sh } \\
\text { or } \\
\text { t } \\
\text { ro } \\
\text { ds }\end{array}$ & $\begin{array}{l}\text { Sh } \\
\text { or } \\
\mathrm{t} \\
\text { ro } \\
\mathrm{ds}\end{array}$ & $\begin{array}{l}\mathrm{C} \\
\text { oc } \\
\text { ci } \\
\text { in } \\
\text { tet } \\
\text { ra } \\
\text { d }\end{array}$ \\
\hline $\begin{array}{l}\text { Moti } \\
\text { lity }\end{array}$ & - & - & - & - & - & - & - & - & - & - & - & - & - & - & - & - & - & - & - & - & - & - & - & - \\
\hline $\begin{array}{l}\text { Gra } \\
\text { m }\end{array}$ & + & + & + & + & + & + & + & + & + & + & + & + & + & + & + & + & + & + & + & + & + & + & + & + \\
\hline $\begin{array}{l}\text { Cata } \\
\text { lase }\end{array}$ & - & - & - & - & - & - & - & - & - & - & - & - & - & - & - & - & - & - & - & - & - & - & - & - \\
\hline $\begin{array}{l}\text { Oxy } \\
\text { dase }\end{array}$ & - & - & - & - & - & - & - & - & - & - & - & - & - & - & - & - & - & - & - & - & - & - & - & - \\
\hline $\begin{array}{l}\text { Argi } \\
\text { nine }\end{array}$ & + & + & + & - & + & + & - & + & - & + & + & + & - & - & + & + & - & - & + & + & - & + & + & + \\
\hline V.P & - & - & - & - & - & - & - & - & - & - & - & - & - & - & - & - & - & - & - & - & - & - & - & - \\
\hline $\begin{array}{l}\text { Nitr } \\
\text { ate }\end{array}$ & - & - & - & - & - & - & - & - & - & - & - & - & - & - & - & - & - & - & - & - & - & - & - & - \\
\hline $\begin{array}{l}\text { Gela } \\
\text { tin }\end{array}$ & - & - & - & - & - & - & - & - & - & - & - & - & - & - & - & + & - & - & - & - & - & - & - & - \\
\hline $\begin{array}{l}\text { Indo } \\
1\end{array}$ & - & - & - & - & + & - & - & - & + & - & - & - & + & - & + & - & - & - & - & - & - & - & + & - \\
\hline $\begin{array}{l}\mathrm{CO}_{2} \\
\text { from } \\
\text { gluc } \\
\text { ose }\end{array}$ & - & - & + & + & - & - & - & - & - & - & + & - & - & - & + & + & - & - & - & - & - & + & - & - \\
\hline $\begin{array}{l}\text { Case } \\
\text { in }\end{array}$ & - & + & + & - & - & + & - & + & - & - & - & - & + & - & + & - & + & - & - & - & - & + & - & + \\
\hline $\begin{array}{l}\text { Ana } \\
\text { erob } \\
\text { ic } \\
\text { gro } \\
\text { wth }\end{array}$ & + & + & + & + & + & + & + & + & + & + & + & + & + & + & + & + & + & + & + & + & + & + & + & + \\
\hline
\end{tabular}

$(-)$ : negative test; $(+)$ : positive test

Table 4:- Sugar fermentation profile of the LAB isolated from ready to drink zoom-koom.

\begin{tabular}{|l|l|l|l|l|l|l|l|l|l|}
\hline $\begin{array}{l}\text { Codes of } \\
\text { isolates }\end{array}$ & Fructose & Glucose & Maltose & Starch & Saccharose & Lactose & Xylose & Raffinose & Arabinose \\
\hline SA1 & + & + & + & - & & & & & \\
\hline SA2 & + & + & + & - & + & - & - & + & - \\
\hline SA3 & + & + & + & + & + & - & - & + & - \\
\hline SA4 & + & + & + & - & + & + & + & + & + \\
\hline SA5 & + & + & + & - & + & - & - & + & + \\
\hline SA6 & + & + & - & - & - & - & - & - & - \\
\hline SA7 & + & + & - & + & - & + & + & - & + \\
\hline SA8 & + & + & + & + & + & + & + & - & - \\
\hline SA9 & + & + & + & + & + & + & + & + & + \\
\hline SA10 & + & + & + & + & + & + & + & + & + \\
\hline SA11 & + & + & + & + & + & + & - & + & + \\
\hline
\end{tabular}




\begin{tabular}{|c|c|c|c|c|c|c|c|c|c|}
\hline SA12 & + & + & + & + & + & + & + & + & + \\
\hline SA13 & + & + & - & + & + & + & - & - & - \\
\hline SA14 & + & + & + & - & + & - & - & - & - \\
\hline SA15 & + & + & + & - & + & + & + & + & + \\
\hline SA16 & + & + & + & - & + & - & + & + & + \\
\hline SA17 & + & + & + & + & + & + & + & + & + \\
\hline SA18 & + & + & - & - & + & - & - & - & - \\
\hline SA19 & + & + & + & + & + & + & + & + & + \\
\hline SA20 & + & + & + & - & + & - & - & + & + \\
\hline SA21 & + & + & + & - & + & + & - & + & - \\
\hline SA22 & + & + & + & - & + & + & - & + & + \\
\hline SA23 & + & + & + & - & + & - & + & + & + \\
\hline SA24 & + & + & - & - & - & + & - & - & + \\
\hline $\begin{array}{l}\% \text { of } \\
\text { isolates } \\
\text { with } \\
\text { positive } \\
\text { reaction }\end{array}$ & 100 & 100 & 79.16 & 41.66 & 87.5 & 62.5 & 50 & 70.83 & 62.5 \\
\hline
\end{tabular}

$(-)$ : negative test; (+): positive test

Table 5:- Identification of the LAB isolated from ready to drink zoom-koom.

\begin{tabular}{|c|c|c|}
\hline Codes of isolates & Identification : sequencing +rep PCR & $\%$ similarity \\
\hline SA1 & Lactobacillus plantarum subsp. plantarum & 99,75 \\
\hline SA2 & Pediococcus pentosaceus & 100 \\
\hline SA3 & Lactobacillus fermentum & 99,36 \\
\hline SA4 & Lactobacillus plantarum subsp. plantarum & 99,75 \\
\hline SA5 & Pediococcus pentosaceus & 100 \\
\hline SA6 & Pediococcus pentosaceus & 100 \\
\hline SA7 & Pediococcus pentosaceus & 99,73 \\
\hline SA8 & Lactobacillus plantarum subsp.plantarum & 99,75 \\
\hline SA9 & Lactobacillus plantarum subsp.plantarum & 99,75 \\
\hline SA10 & Lactobacillus plantarum subsp.plantarum & 99,75 \\
\hline SA11 & Lactobacillus fermentum & 99,36 \\
\hline SA12 & Lactobacillus plantarum subsp.plantarum & 99,73 \\
\hline SA13 & Pediococcus pentosaceus & 100 \\
\hline SA14 & Pediococcus pentosaceus & 100 \\
\hline SA15 & Lactobacillus fermentum & 99,36 \\
\hline SA16 & Lactobacillus fermentum & 99,36 \\
\hline SA17 & Lactobacillus plantarum subsp.plantarum & 99,75 \\
\hline SA18 & Pediococcus pentosaceus & 100 \\
\hline SA19 & Lactobacillus plantarum subsp.plantarum & 99,75 \\
\hline SA20 & Pediococcus pentosaceus & 100 \\
\hline SA21 & Lactobacillus plantarum subsp.plantarum & 99,75 \\
\hline SA22 & Lactobacillus fermentum & 99,36 \\
\hline SA23 & Lactobacillus plantarum subsp. plantarum & 99,75 \\
\hline SA24 & Pediococcus pentosaceus & 100 \\
\hline
\end{tabular}


Table 6:- Sugar fermentation profile of the isolates of identified LAB species predominant in ready to drink zoomkoom.

\begin{tabular}{|l|l|l|l|l|l|l|l|l|l|}
\hline & Glucose & Fructose & Saccharose & Maltose & Raffinose & Arabinose & Lactose & Xylose & Starch \\
\hline $\begin{array}{l}\text { L. } \\
\text { plantarum } \\
\text { subsp. } \\
\text { plantarum } \\
(\mathrm{n}=10)\end{array}$ & $100 \%$ & $100 \%$ & $100 \%$ & $100 \%$ & $90 \%$ & $80 \%$ & $80 \%$ & $80 \%$ & $60 \%$ \\
\hline $\begin{array}{l}\text { L. } \\
\text { fermentum } \\
\mathrm{n}=5)\end{array}$ & $100 \%$ & $100 \%$ & $100 \%$ & $100 \%$ & $100 \%$ & $80 \%$ & $80 \%$ & $60 \%$ & $40 \%$ \\
\hline $\begin{array}{l}P . \\
\text { pentosaceus } \\
(\mathrm{n}=9)\end{array}$ & $100 \%$ & $100 \%$ & $66.66 \%$ & $44.44 \%$ & $33.33 \%$ & $33.33 \%$ & $33.33 \%$ & $11.11 \%$ & $22.22 \%$ \\
\hline
\end{tabular}

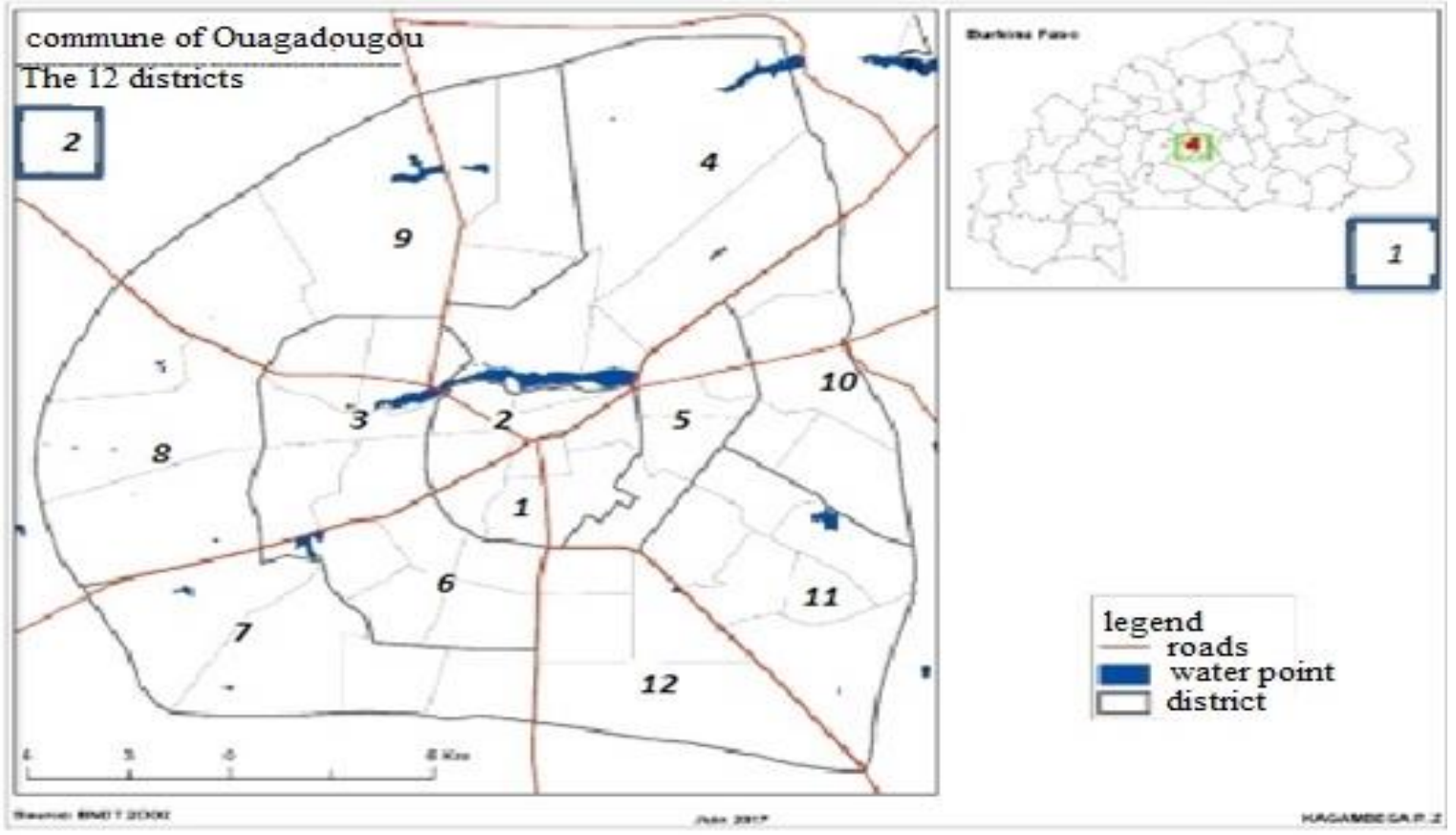

Fig 1:- Chart of Burkina Faso presenting the geographical localisation of Ouagadougou (1); city of Ouagadougou illustrating the 12 districts (2). 


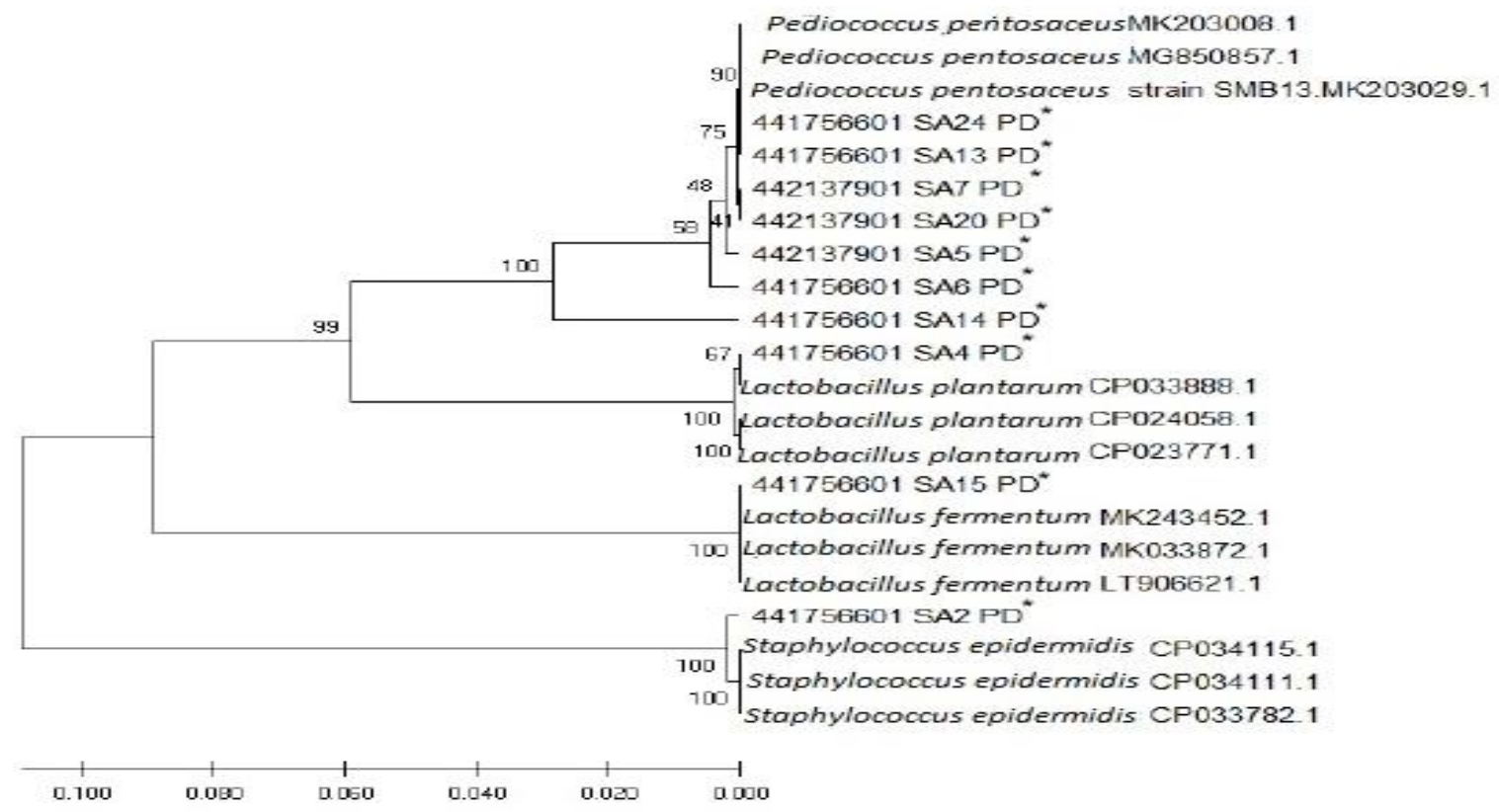

Fig 2:- UPGMA tree based on 16S rDNA sequences of selected LAB isolates and GenBank related reference. strains. $(*)$ : selected LAB isolates

\section{References:-}

1. Amoa-Awua, W.K.A., Appoh, F.E. and Jakobsen, M. (1996): Lactic acid fermentation of cassava dough into agbelima. Int. J. Food Microbiol., 31: 87-98.

2. Amusa, N.A. and Ashaye, O.A. (2009): Effet of processing on nutritional, microbiological and sensory properties of kunun-zaki (a sorghum based non-alcoholic beverage) widely consumed in Nigeria. Pakistan J. Nutr., 8 (3): 288-292.

3. Barro, N., Bello, A.R., Itsiembou, Y., Savadogo, A., Ouattara, A.T.C., Nikiema, A.P.P., De Souza, C., Traoré, A.S. (2007): Street-vended foods improvement: contamination mechanisms and application of food safety objective strategy: critical review. Pakistan J. Nutr., 6 (1): 1-10.

4. Barrow, G.H. and Feltham, R.K.A. (1993): Cowan and Steel's Manual for Identification of Medical Bacteria. 3rd Edition, Cambridge University Press, Cambridge, p331. http://dx.doi.org/10.1017/CBO9780511527104.

5. Belhamra, Z., Harzallah, D., Naili, O. and Belhadj, H. (2016): Probiotic potential of Lactobacillus strains isolated from fresh bee pollen. Der PharmaLettre. (19):357-365.

6. Bsadjo-Tchamba, G., Bawa, I.H., Nzouankeu, A., Bagré, T.S., Dembélé, R., Bonkoungou, I.J.O., Zongo, C., Savadogo, A., Traoré, A.S. and Barro, N. (2014): Occurrence and antimicrobial susceptibility of Escherichia coli and Salmonella spp. isolated from "zoom-koom" beverage and ice in Ouagadougou, Burkina Faso. Afr. J. Microbiol. Res., 8(35): 3243-3249.

7. Critères microbiologiques applicables aux denrées alimentaires (CMADA) du Gouvernement du Grand Duché de Luxembourg : Lignes directrices pour l'interprétation. (2018): Ministère de la Santé. Direction de la Santé. $57 \mathrm{p}$.

8. De Angelis, M., Siragusa, S., Berloco, M., Caputo, L., Settanni, L., Alfonsi, G., Amerio, M., Grandi, A., Ragni, A. and Gobbetti, M. (2006): Selection of potential probiotic lactobacilli from pig feces to be used as additives in pelleted feeding. Res. Microbiol., 157: 792-801.

9. Efiuvwevwere, B.J.O. and Akona, O. (1995): The microbiological of kunun-zaki, a cereal beverage from northern Nigeria during the fermentation (production) process. World J. Microbiol. Biotechno., 11: 491-493.

10. Elmahmood, A.M. and Doughari, J.H. (2007): Microbial quality assessment of kunun-zaki beverage sold in Gerei town of Adamawa State, Nigeria. Afr. J. Food Sci., pp 011-015. 
11. Ennadir, J., Hassikou, R., Al Askari, G., Arahou, M. and Bouazza, F. (2014): Caractérisation phénotypique et génotypique des bactéries lactiques isolées des farines de blé d'origine marocaine. J. Mater. Environ. Sci., 5 (4): 1125-1132.

12. Gregersen. (1978): A rapid method for distinction of Gram-negative from Gram positive bacteria. Eur. J. Appl. Microbiol Biotechno., 5:123-127.

13. Guiraud, J.P. (1998): Microbiologie Alimentaire. DUNOD, Paris. France. pp 282-295.

14. ISO7402(1993):Microbiologie-Directives générales pour le dénombrement sans revivification des Enterobacteriaceae-Technique NPP et méthode par comptage des colonies, $7 \mathrm{p}$.

15. ISO7954(1988):Directives générales pour le dénombrement des levures et moisissures,techniques par comptage des colonies à $25^{\circ} \mathrm{C}, 4 \mathrm{p}$.

16. ISO15214(1998):Microbiologie des aliments-Méthode horizontale pour le dénombrement des bactéries lactiques mésophiles-Technique par comptage des colonies à $30^{\circ}$ degrés Celsius, $7 \mathrm{p}$.

17. Lei, V. and Jakobsen, M. (2004): Microbiological characterization and probiotic potential of koko and koko sour water, African spontaneously fermented millet porridge and drink. J. Appl. Microbiol. 96: 384-397.

18. Messens, W. and De Vuyst, L. (2002): Inhibitory substances produced by Lactobacilli isolated from sourdoughs-a review. Int. J. Food Microbiol, 72(1-2): 31-43.

19. Ouoba, L.I.I., Parkouda, C., Diawara, B., Scotti, C. and Varnam, A.H. (2008): Identification of Bacillus spp from Bikalga, fermented seeds of Hibiscus sabdariffa phenotypic and genotypic characterization, J. Appl. Microbiol., 104: 122-131.

20. Ouoba, L.I.I., Nyanga-Koumou, C.A.G., Parkouda, C., Sawadogo-Lingani, H., Kobawila, S.C., Keleke, S., Diawara, B., Louembe, D. and Sutherland, J.P. (2010): Genotipic diversity of lactic acid bacteria isolated from African traditional alkaline fermented foods. J. Appl.Microbiol., 108 (2010): 2019-2029.

21. Ouoba, L.I.I., Kando, C., Parkouda, C., Sawadogo-Lingani, H., Diawara, B. and Sutherland, J.P. (2012): The microbiology of Bandji, palm wine of Borassus akeassii from Burkina Faso: identification and genotypic diversity of yeasts, lactic acid and acetic acid bacteria. J.Appl. Microbiol., 113(6):1428-1441.

22. Sawadogo-Lingani, H., Diawara, B., Traore, A.S. and Jakobsen, M. (2007): Technological properties of Lactobacillus fermentum involved in the processing of dolo and pito, West African sorghum beers, for the selection of starter cultures. J. Appl. Microbiol., 104 (2008):873-882.

23. Sawadogo-Lingani, H., Diawara, B., Traoré A.S. and Jakobsen, M. (2008): Utilisation des souches sélectionnées de Lactobacillus fermentum et un isolat de levures comme cultures starter dans la production du dolo, une boisson fermentée à base de sorgho. Sci. Tech., 2:61-84.

24. Sawadogo-Lingani, H., Diawara, B., Glover. R., Tano-Debrah, K., Traore, A.S. and Jakobsen, M. (2010): Predominant lactic acid bacteria associated with the traditional malting of sorghum grains. African J. Microbiol. Res. 4 (3): 169-179.

25. Soma, M.A.A.R., Tapsoba, F.W., Kaboré, D., Toguyeni, A., Tankoano, A., Dicko, M.H. and SawadogoLingani, H. (2017): Etude sur la capacité de production, du circuit de commercialisation et de la consommation du zoom-koom vendu dans la ville de Ouagadougou au Burkina Faso. Int. J.Biol.Chem. Sci., 11(5): 2294-2305.

26. Soma, M., Kaboré, D., Tankoano, A., Compaoré, C.S., Parkouda, C., Toguyeni, A. and Sawadogo-Lingani, H. (2019): Improvement of nutritional, sanitary and organoleptic qualities of liquid zoom-koom and instant flour zoom-koom using Lactobacillus fermentum starter culture. Afr. J.Biotechno., 18(9): 181-196.

27. Sunday, P.U., Nyaudoh, U.N. and Etido, J.U. (2011): Microbiological quality and safety evaluation of fresh juices and edible ice sold in Uyo Metropolis, South-South, Nigeria. Int. J. Food Saf, 13: 374-378.

28. Taalé, E., Savadogo, A., Zongo, C., Tapsoba, F., Karou, S.D. et Traore, A.S. (2016b): Les peptides antimicrobiens d'origine microbienne: cas des bactériocines. Int. J. Biol. Chem. Sci., 10(1): 384-399.

29. Tapsoba, F.W.,Sawadogo-Lingani, H.,Kabore, D.,Compaore-Sereme, D. andDicko, M.H. (2017a):Effect of the fermentation on the microbial population occurring during the processing of zoom-koom, a traditional beverage in Burkina Faso,Afr.J.Microbiol. Res.,11(26):1075-1085.

30. Tapsoba, F.W.,Sawadogo-Lingani, H., Coda, R., Compaoré-Sérémé, D., Katina, K., Kaboré, D., Haro, H., Dicko, M.H. and Maina, H.N. (2017b): Characterization of exopolysaccharides producing-LAB isolated from zoom-koom, a cereal-based traditional beverage from Burkina Faso. Int. J. Biosci., 11(6):45-60. http://dx.doi.org/10.12692/ijb/11.6.45-60

31. Tapsoba, F.W., Sawadogo-Lingani, H., Kaboré, D., Zongo, S., Compaoré-Sérémé, D. and Dicko, M.H. (2018): Controlled fermentation of the zoom-koom dough using two isolates of lactic acid bacteria (LAB 1 and LAB 5) as starter cultures: Effect on hygienic, rheological, nutritional and sensorial characteristics of the final product. Afr. J. Biotechno., 17(5): 96-107.DOI: 10.5897/AJB2017.16306. 
32. Tchekessi, C.K., Bokossa, A., Adigun, N., Bleoussi, R., Sachi, P., Banon, J., Agbangla, C., Azokpota, P. et Bokossa, Y. (2014a) :Physico-chemical and sensory characterizations of three types of "dèguè", a local fermented drink made from milk in Benin. Int. J. Biosci., 5(3): 36-43. doi: 10.12692/ijb/5.3.36-43.

33. Thomas, L.V., Clarkson, M.R. and Delves-Broughton, J. (2000): Nisin. In: Naidu, A. S.(Eds).Natural Food Antimicrobial Systems. CRC-Press. F. L. pp 463-524.

34. Wang, L.T., Lee, F.L., Tai, C.J. and Kasai, H. (2007): Comparison of gyrB gene sequences, 16S rRNA gene sequences and DNA-DNA hybridization in the Bacillus subtilis group. Int. J. Syst. Evol. Microbiol., 57: 1846-1850.

35. Yoon, S.H., Ha, S.M., Kwon, S., Lim. J., Kim, Y., Seo, H. and Chun, J. (2017): Introducing EzBioCloud: a taxonomically united database of $16 \mathrm{~S}$ rRNA gene sequences and whole genome assemblies. Int. J. Syst. Evol. Microbiol., 67(5):1613-1617. 